\title{
Research on the Mechanism of Precision Poverty Alleviation in Industry Poverty Alleviation-Taking Aba Prefecture as an Example
}

\author{
Chen Ruoqi, Zheng Yuhang*, Song Ye Wei, Liu Peisong \\ Commercial college, Sichuan Agricultural Uniersity, Sichuan, China, 611830 \\ *Corresponding Author email: 2545196963@qq.com
}

Keywords: Aba Prefecture; industrial poverty alleviation; precision poverty alleviation mechanism; hematopoietic function

\begin{abstract}
As one of the important ways to tackle poverty and solve the problem of employment, industrial poverty alleviation is of great significance to help the impoverished families to reach the well-off society in a comprehensive way. In recent years, although the poverty-stricken areas such as prefecture have achieved initial results, there are some problems to be solved in the mechanism of targeted poverty alleviation. The benefit linking mechanism and the industry poverty alleviation mechanism are not perfect, which leads to the inefficiency of the industry and the result of the industry. Based on the existing industrial poverty alleviation model and specific situation in prefecture, this paper analyzes the problems of targeted poverty alleviation mechanism in the industrial poverty alleviation through the local poverty alleviation effect and experience. Through the enhancement of "hematopoietic" function, innovative benefit link mechanism, and so on, help impoverished households to get rid of poverty.
\end{abstract}

\section{Introduction}

"Eliminating poverty, improving people's livelihood and achieving common prosperity" is the essential requirement of socialism and an important condition for achieving social stability and harmonious development [1]. At present, China's rural poverty alleviation has entered a decisive battle to fight the fortress. Eliminating absolute poverty and achieving accurate poverty alleviation is the bottom line goal of building a well-off society in an all-round way, but also a landmark indicator. From the past to the present, Sichuan has first solved the problem of food and clothing, and then consolidated the achievements. At this stage, Sichuan has been moving towards a well-off society in an all-round way, and accelerated the pace of poverty eradication and wealth. However, Sichuan is still on the list of six key poverty-alleviating provinces in China. At present, most of the rural poverty-stricken people are in deep poverty and overall poverty. The cost of poverty alleviation is higher and it is more difficult to get rid of poverty. Especially, extreme poverty still exists in Aba Prefecture, Yi District and other ethnic minority areas. Due to the poor natural conditions, backward ideas, weak economic foundation, lack of funds and other factors, Aba Prefecture and other places return to poverty more prominent, stable poverty relief foundation is still very fragile. Therefore, it is of great significance to investigate the current situation and achievements of poverty alleviation in Aba Prefecture, analyze the existing problems, and explore the suggestions and Countermeasures to innovate the industrial poverty alleviation mechanism for the whole Sichuan Province. Based on the survey data of poverty alleviation in Aba Prefecture, this paper discusses and analyzes the current situation, experience and problems of poverty alleviation.

\section{The effect and experience of industrial poverty alleviation in Aba Prefecture}

In 2020, the whole province will realize the "lifting cap" of all 88 poverty-stricken counties, which is the general task of Sichuan's poverty alleviation. As for Aba Prefecture, in 2017, except Jiuzhaigou County delayed acceptance due to disasters, the remaining four poverty-stricken counties (cities) to 
take off their hats passed the provincial acceptance, 30311 poverty-stricken people steadily out of poverty, 239 villages out of poverty sequence. The incidence of poverty in Aba is decreased by 4 percentage points from last year, which improved the poverty status.

\subsection{Develop characteristic planting and animal husbandry, and increase income and increase production and help to tackle poverty.}

In recent years, Aba prefecture has continuously improved its agricultural development mechanism, taking diversified forms and moderate scale operation as the core, transforming the mode of agricultural production and management. At present, Aba state planted autumn light vegetables, characteristic fruits, wine grapes, low-temperature edible fungi area as high as 796,000 mus. Mainly including Chinese cabbage, onions, vegetables and other basic vegetables, and Maoxian apple, Jinchuan Sydney, sweet cherry, wine grapes, and other characteristics of fruit, the total output of 160.14 million tons. In addition, Aba also focused on base construction and constantly optimized the layout of agricultural industry. Using 717 million agricultural and animal husbandry development funds, Aba will promote the construction of 40,000 mus of modern agricultural demonstration areas, 64 fruit standardization bases with an area of 5,000 mus, and 101,000 mu of grain and oil demonstration areas. In agricultural cooperation, 847 new farming and animal husbandry cooperatives, 51 registered family farms, 13 provincial demonstration cooperatives and 7 provincial demonstration farms were added. Thanks to the concerted efforts of the government and villagers in Aba Prefecture, it has greatly promoted the large-scale operation of the rural areas.

\subsection{Relying on Internet industry to further develop poverty alleviation.}

Poor households through the business platform, to broaden the sales channels of agricultural products, so that better sales of agricultural products, solve the problem of poor household agricultural products unsalable, enhance the market liquidity of agricultural products. HongYuan county relies on electricity providers to expand the "Internet +" new channel for poverty alleviation, and has invested 10 million to build a county level e-commerce service center and a rural e-commerce service station. Relying on the cooperation with Ali, Yunli, Tianmao and other large-scale e-commerce platforms, we have realized the online shopping of enterprises and the on-line sale of local specialty products. The sales volume has been greatly improved. At the same time, we have solved part of the employment staff through the supporting services of commercial enterprises, so as to achieve a win-win situation for both producers and consumers.

\subsection{Actively respond to the call of the state to develop green ecosystems.}

Aba Prefecture devotes all efforts to developing green ecological agriculture and actively responds to the call of the state. The green coverage rate of urban built-up areas in Aba Prefecture is expected to reach $15.5 \%$, the green space rate to reach $11.7 \%$, and the per capita park green space area to reach 6.8 square meters. For example, in Wenchuan, the core of the base construction is to optimize the industrial layout. Based on abundant resources and location, actively cultivate and support the development of family farms, related professional associations and other animal husbandry economic system.

\subsection{Relying on natural resources to develop tourism industry.}

Aba Prefecture, located on the Western Sichuan Plateau, has natural tourist resources. Pleasant climate and beautiful scenery, give Aba tourism to get rich opportunities. In 2017, Aba Prefecture has 21.4 million for the development of tourism industry, with Jiuzhaigou, Huanglong and Wenchuan special tourist areas of Grade 5A, Siguniangshan, Dagu iceberg, Wenchuan Dayu cultural tourist area, Maoxian Qiangxiang ancient village and 11 4A scenic spots. Last year, 29 million 95 thousand and 800 tourists were received and the total tourism revenue was 23.572 billion. In recent years, ABA is committed to helping the poor through tourism. Firstly, taking the opportunity of establishing a national tourism poverty alleviation demonstration area, the pilot work of tourism poverty alleviation will be accelerated. 14 villages, including Yatun, Wujiao Township and Ying, in Zhangzha Town, 
Jiuzhaigou County, will be included in the "provincial tourism poverty alleviation demonstration village" of Jiuzhaigou County.

\begin{tabular}{|c|c|c|c|c|c|c|c|c|}
\hline 市(州) & Region & 2010 & 2011 & 2012 & 2013 & 2014 & 2015 & 2016 \\
\hline 成都市 & Chengdu & 5551.33 & 6950.58 & 8138.94 & 9108.89 & 10056.59 & 10801.16 & 12170.23 \\
\hline 自贡市 & Zigong & 647.73 & 780.36 & 884.80 & 1001.60 & 1073.40 & 1143.11 & 1234.56 \\
\hline 攀枝花市 & Panzhihua & 523.99 & 645.66 & 740.03 & 800.88 & 870.85 & 925.18 & 1014.68 \\
\hline 沾州市 & Luzhou & 714.79 & 900.87 & 1030.45 & 1140.48 & 1259.73 & 1353.41 & 1481.91 \\
\hline 德阳市 & Deyang & 921.27 & 1137.45 & 1280.20 & 1395.94 & 1515.65 & 1605.06 & 1752.45 \\
\hline 绵阳市 & Mianyang & 960.22 & 1189.11 & 1346.42 & 1455.12 & 1579.89 & 1700.33 & 1830.42 \\
\hline 广元市 & Guangyuan & 321.87 & 403.54 & 468.66 & 518.75 & 566.19 & 605.43 & 660.01 \\
\hline 遂宁市 & Suining & 491.50 & 582.47 & 656.00 & 736.61 & 809.55 & 915.81 & 1008.45 \\
\hline 内江市 & Neijiang & 690.28 & 854.68 & 978.18 & 1069.34 & 1156.77 & 1198.58 & 1297.67 \\
\hline 乐山市 & Leshan & 743.92 & 918.06 & 1037.75 & 1134.79 & 1207.59 & 1301.23 & 1406.58 \\
\hline 南充市 & Nanchong & 827.82 & 1029.48 & 1180.36 & 1328.55 & 1432.02 & 1516.20 & 1651.40 \\
\hline 眉山市 & Meishan & 552.25 & 673.34 & 775.22 & 860.04 & 944.89 & 1029.86 & 1117.23 \\
\hline 宜宾市 & Yibin & 870.85 & 1091.18 & 1242.76 & 1342.89 & 1443.81 & 1525.90 & 1653.05 \\
\hline 广安市 & Guangan & 537.22 & 659.90 & 752.22 & 835.14 & 919.61 & 1005.61 & 1078.62 \\
\hline 达州市 & Dazhou & 819.20 & 1011.83 & 1135.46 & 1245.41 & 1347.83 & 1350.76 & 1447.08 \\
\hline 雅安市 & Yaan & 286.54 & 350.13 & 398.05 & 417.97 & 462.41 & 502.58 & 545.33 \\
\hline 巴中市 & Bazhong & 264.98 & 326.67 & 372.40 & 415.94 & 456.66 & 501.34 & 544.66 \\
\hline 资阳市 & Ziyang & 657.90 & 836.44 & 984.72 & 1092.36 & 1195.60 & 1270.38 & 943.44 \\
\hline 阿坝藏族芫族自治州 & Aba & 132.76 & 168.48 & 203.74 & 233.99 & 247.79 & 265.04 & 281.32 \\
\hline 甘孜藏族自治州 & Ganzi & 122.83 & 152.22 & 175.02 & 201.22 & 206.81 & 213.04 & 229.80 \\
\hline 凉山祭族自治州 & Liangshan & 784.19 & 1000.13 & 1122.67 & 1214.40 & 1314.30 & 1314.84 & 1403.92 \\
\hline
\end{tabular}

Figure 1. Gross domestic product of each province in Sichuan Province

\section{Problems found in poverty alleviation in Aba Prefecture}

\subsection{Poverty alleviation caused by imperfect mechanism of industrial poverty alleviation to households.}

The purpose of poverty alleviation is to help the poor to lead a well-off life, and the precise "drip irrigation" household mechanism plays an extremely important role in this process. As far as the mechanism of industrial poverty alleviation to households is concerned, there are some problems in some areas, such as "utilitarianism" in the target and subject of poverty alleviation, inaccurate identification of poverty alleviation, and "congenital deficiency" and "acquired imbalance" in rural areas. In 2017, six typical cases of violation of discipline in the field of poverty alleviation were notified by Aba State Discipline Inspection Commission. Among them, the default of the mass subsidy funds, the private allocation of special funds by the cadres of poverty alleviation, the embezzlement of infrastructure construction funds and the failure of high-level cadres to check the accurate identification of poverty alleviation seriously hindered the process of poverty alleviation.

\subsection{The industrial chain of agricultural poverty alleviation is short.}

Abundant green resources are the precious wealth endowed by nature to Aba Prefecture. However, the weakness of Aba Prefecture's agriculture is obvious, mainly primary agricultural products, and the processing depth is not enough. Aba Prefecture relies on plum, cabbage and other vegetable and fruit agricultural resources to drive poverty-stricken households out of poverty and become rich, but has not formed a national influence, high-quality green well-known brands. The number of large leading companies is small and the industry chain is short. 2 leading enterprises at the provincial level, 9 state-level. From this, we can see that the market competitiveness of agricultural products is low and the ability to resist risks is weak. The income of the poor households is fluctuated by the market, the income cannot be stable, and the effectiveness of poverty alleviation cannot be guaranteed.

\subsection{There are problems in the mechanism of industrial poverty alleviation.}

Interest linkage mechanism refers to the interest linkage formed by "risk sharing and benefit sharing" among poor households, enterprises and local governments. However, in the actual investigation, due to the great difference in market strength between enterprises and poor households, the information asymmetry between the three main bodies, and the differences in cognition and objectives between local governments and poor households, the interest linkage mechanism among the three is loose, the "center of gravity" is partial to one side, and the poor households are fail to benefit from it. As far as Aba Prefecture is concerned, it fails to achieve the phenomena of 
"guaranteeing bottom income and dividend according to shares", resulting in losses and no gains for poor households.

\subsection{The formalization of "hematopoiesis" mode of industrial poverty alleviation has not played an effective role.}

At present, Aba state's poverty alleviation has not fundamentally changed from "blood transfusion" to "hematopoiesis". Farmers still rely on government subsidies to a certain extent, lack of initiative, and do not effectively use technology and funds to fundamentally alleviate poverty. During the investigation and visits, some peasant households still maintain their livelihood through government relief, adhere to the traditional industrial model, stick to self-styled, formalize the innovative industrial poverty alleviation model, do not internalize the use, and even have the fear of getting rid of poverty. How to mobilize the enthusiasm of farmers to help ABA to achieve "hematopoiesis" to help the poor is imminent.

\section{The way to optimize poverty alleviation in Aba Prefecture}

\subsection{Continue to promote the "all-coverage, strong supervision, zero tolerance" supervision and accountability attitude in Aba Prefecture, and increase the intensity of legal publicity and education in the field of poverty alleviation.}

Accurate poverty alleviation is related to the national plan. It should not only be strictly checked and accurately identified, but also prevent the corruption of special funds, fraudulent poverty alleviation projects, jerry-building and other issues. The villagers in Aba Prefecture are simple in style and lack the awareness of relevant laws and regulations for poverty alleviation, which gives them a larger living space for poverty alleviation and corruption alleviation. In addition, Aba prefecture government has adopted "night school law, discipline" and "field topography policy" to carry out publicity and education in 223 townships (towns) and 1354 administrative villages, and set up "problems, supervision, and rectification" three accounts. But in the gaps between the inspections, there is still small-scale corruption; formalism still exists in most legal systems or supervision propaganda. Aba Prefecture should innovate and improve the system of villagers' democratic inquiry and comment and the villagers' Congress on the topic of Party conduct and clean government; smooth the path of mass participation, expand the channels of reporting, pay attention to any reports from the masses, strengthen vigilance, deal with seriously, implement the reality, and strengthen the important position of poor households in poverty alleviation supervision.

\subsection{Strengthen the brand effect, widen the industrial chain.}

Mak full use of natural and high-quality natural resources, create green ecological agricultural products, poor households jointly register trademarks, and form influential brands. The government should strengthen the guidance of leading enterprises, broaden the industrial chain, enhance the market competitiveness and sales share of products. . At the same time, we should make full use of natural resources and natural gifts to develop leisure agriculture, green agriculture, cultural tourism and other new industrial growth points. For example, Xiaojin County, Aba Prefecture, promotes stable incomes of poor households by developing stable and precise industries. Vigorously develop the "small gold production" brand, such as: small gold pine, small golden apple. At present, 80,000 mu of ecological vegetables, wine grapes, authentic Chinese medicinal materials and 44 scientific management farms have been built, 4 organic green foods have been certified, and rural tourism has been strengthened. There are 9 rural tourism poverty-alleviation demonstration villages. 


\subsection{Build a close interest community of local governments, leading enterprises and poor households three.}

In the process of precise poverty alleviation, we should realize the linkage mechanism of "beneficial sharing, risk sharing", enhance the status of poor households in industrial poverty alleviation, and deepen the links between products and markets. At the same time, we should standardize the three-party restraint mechanism, clarify the rights and obligations of the three parties, supervise and promote each other, and adhere to the transparency of industrial poverty alleviation information and the sharing of resources. Between local governments and enterprises, local governments should provide some preferential policies and technical support for leading enterprises; between leading enterprises and poor households, enterprises should establish a risk-sharing mechanism with poor households to prevent poor households from becoming "victims" of industrial poverty alleviation; and between the government and poor households, the government should increase Poverty alleviation funds provide more policy preferences for archiving card holders. In order to prevent poverty-stricken households from being marginalized in the interest-linked system, it is necessary to specify the proportion of the three parties, to buy some natural and market risk insurance for poverty-stricken households, to lighten the burden of farmers through insurance, to better connect enterprises and local governments, to minimize the risk of the three parties and to maximize the benefits.

\subsection{Rational collocation of diversified combinations of agricultural products to maximize the benefits [5].}

In the selection of poverty-stricken households and villages for industrial poverty alleviation projects, we should not only "blow the chaff and see the rice immediately", but also adhere to sustainable development, combining strengths and weaknesses, constantly consolidating, and preventing the rebound effect. For example: in the short run to run pheasants, Tibetan pigs * and other aquaculture industry, mainly in the long term iron bar hammer, rhubarb and other slow effect of Chinese herbal medicine, and vigorously develop characteristic agriculture, establish vegetable base, strengthen the collective economy.

\subsection{Establish a "poor households + Internet + cooperative" interest linking mode to help industry develop poverty alleviation [6].}

In line with the national poverty alleviation development focus, we should innovate the poverty alleviation mechanism based on e-commerce, "poor households + Internet + cooperatives". Through the measures of "e-commerce" to the countryside, we will improve the service station equipment and help the poor households expand the sale of agricultural products. Wenchuan County has made great efforts to build e-commerce and rural demonstration counties, and eight e-commerce "eat-all" service sites have been set up in villages and towns, opening up a new path for e-commerce to help people get rid of poverty accurately. Up to now, Xiaojin County has built an e-commerce Industrial Park and a warehouse logistics center through the development of the e-commerce industry, and has joined 15 enterprises and 34 e-commerce merchants to build 89 rural e-commerce service centers. Wenchuan County has trained more than 3,000 e-commerce personnel, of which more than 20 have been trained. "Electricity providers + disabled" training disabled people. Through the one-stop service of "Tongshi" website, the net sales of fruit products amounted to more than 50 million, and the net purchases of tourism and catering amounted to 150 million.

\subsection{Change the old pattern of poverty alleviation, and promote the transformation from "blood transfusion" to "hematopoiesis".}

Implement the "wisdom + aspiration" two-way assistance, strengthen the "college students' entrepreneurship + innovation" mechanism, and at the same time "rich first to drive the rich later" to carry out the local talent mentor training program: First, make the poor households internalize the use of technology and funds, in order to stimulate the poor households to get rid of poverty, cut off the 
"root causes" of poverty. We should strengthen the close ties between college students and ABA and promote the development of talents in Aba Prefecture. Establish and improve the talent pool network, employ local talents as mentors, carry out the engineering training of becoming rich and talented people, and establish a talent training program. At present, Aba's Wori River region has established a university student entrepreneurship, internship, employment base, has a characteristic product research and development center, combined with the advantages of the local four girls, two river clubs, to build incubators such as incubators and venture capital.

\section{References}

[1] He Fangbin. The relationship between scientific development and improving people's livelihood [1006-1754]. Party and government forum.2016.2.

[2] Our journal. The voice of cooperatives in local "two sessions". Chinese farmer cooperatives. 2015.4

[3] Wang Guo Hong. The current predicament facing the precise poverty alleviation and Its Countermeasures.2017.05.

[4] Qiu Fugui. Study on the Industrialization of Animal Husbandry in Horqin Agricultural Area [J]. Inner Mongolia Normal University, 2011

[5] Yangwuping. Analyse of Farmers' Choice under the Adjustment of Agricultural Structure [N]. Grain Science, Technology and Economy, March2011

[6] Yu Xing Fu. Ziyang's "flexible mode" for industrial poverty alleviation [A]. Contemporary Shaanxi. 2016.02 